\title{
Acoustics of Orthodox Churches in Poland
}

\author{
Paweł MAŁECKI ${ }^{(1)}$, Jerzy WICIAK ${ }^{(1)}$, Damian NOWAK ${ }^{(2)}$ \\ (1) Department of Mechanics and Vibroacoustics, AGH University of Science and Technology \\ Al. A. Mickiewicza 30, 30-059 Kraków, Poland; e-mail: pawel.malecki@agh.edu.pl \\ (2) Institute of History, University of Rzeszów \\ Al. Rejtana 16C, 35-310 Rzeszów, Poland; e-mail: cerkwie@gmail.com \\ (received February 23, 2017; accepted June 13, 2017)
}

\begin{abstract}
An Orthodox church as a building expresses the Eastern Orthodox spirituality - all the details and general aspects have a deep and philosophical meaning. The architecture, being an illustration of the character of the Orthodox Church liturgy, has become a natural component of the cultural landscape of Poland and Eastern Europe. Acoustic research into Orthodox churches has so far been marginalized. Up to now, only a few churches of this type have been studied. The article is a review of the acoustic environment of churches in Poland. Churches, differing in terms of size, architectural style and other quantities, were chosen and acoustic measurements were made. The results of the measurements have been analyzed and collated. In particular, a detailed analysis and comparison was made for reverberation time as a function of frequency, due to the largest differences in this parameter between the rooms.
\end{abstract}

Keywords: orthodox churches; room acoutics.

55.006: Gx - Studies of existing auditoria and enclosures.

\section{Introduction}

Studies concerning the Eastern Rite Churches in Poland (Krasny, 2003) are evidence of the connection between the Byzantine culture and the history of this part of Europe. The churches constitute the architectural landscape; however, first and foremost, they are the houses of worship for Eastern Orthodox, Greek Catholic and Roman Catholic Church congregations (KoŁbuK, 1998).

The topic of Orthodox church acoustics is rarely present in the literature. The few published works, e.g. (Mijic, Sumarac-Pavlovic, 2000), (Mijic, 2001), discuss Balkan Orthodox churches. Recent work (Elicio, Martellotta, 2015) describes in detail the acoustics of the Orthodox Church of San Nicola (also known as the "Russian Church") in Bari, but it also includes an interesting set of the main characteristics of selected Orthodox churches in Russia and Greece. All this data constitutes a very important point of reference for the current work, due to the similar church tradition, language (only for Russian and Balkan churches) and music character.

Many other works by various authors are dedicated to the topic of Catholic churches, among others: (Állvarez-Morales et al., 2014; 2015; 2016; Carvalho, Morgado, 1997; Galindo et al., 2000;
Kosala, 2013; 2016; Martellotta et al., 2008; 2009; 2016; PleWA, 2007; VAliÈRe et al., 2013) and (Lubman, Wetherill, 1985). These works cover a very broad spectrum of Catholic church acoustics. They include analysis of monumental basilicas in Italy and Spain, together with some scope on research methodology (among others: Álvarez-Morales, 2015; Martellotta, 2009). Polish churches have been intensively studied by Kosala (2013) and WroblewSKa (2007), with analysis by Kosala (2013) followed by formulation of a versatile assessment index.

This article contains the results of acoustic and basic architectural measurements of the Orthodox churches located in Eastern Europe, while discussing only the buildings in Poland. They illustrate, up to a point, the changeability of the interiors of this kind - both in a general context and in reference to Poland only. The largest aggregation of churches is in Northeastern Poland (mainly Podlasie and the Lubelskie Region) and, on a smaller scale, in Southern Poland. The fundamental factor that makes the churches different is the main material they are built from. The clear majority of churches built before 1914 are wooden churches (BRYKOWSKI, 1995). Because of the differing qualities of wood, brick, stone, daub or other materials available, the choice of the main material is very important. The age of the wood is also essential. Wood, in com- 
parison to a brick-built surface, changes its qualities more visibly as the time passes. The churches can also be classified based on their architectural style, solid geometry, size, shape, spatial composition, the design of the foundation, decor and other factors discussed more specifically in the following chapters.

\section{Measurement method}

Measurements of the acoustic parameters were made in 20 churches in Poland. Cataloging and measuring the rooms, differing in terms of size, architectural style and other characteristic qualities, was conducted. The measurements were performed in unoccupied conditions. To determine the Spatial Impulse Responses, EASERA software and authorial scripts implemented in the MATLAB environment were used. The measurements were made by following the basic standards in the field of room acoustics (ISO 3382, 2009). However, because of the character of the rooms and the technical limitations, some simplifications have been introduced. Instead of a sound source of omnidirectional characteristics, a JBL EON 515 active loudspeaker was used. Its parameters were analyzed and described in (MAŁECKI et al., 2011). Its maximum level is $132 \mathrm{~dB}$ SPL and frequency response of $42 \mathrm{~Hz}-18 \mathrm{kHz}$ with $\pm 3 \mathrm{~dB}$ margin. Its horizontal and vertical coverage $(-6 \mathrm{~dB})$ is $100^{\circ} \times 60^{\circ}$ which is between human mouth directivity and Genelec 1029A directivity, as investigated by SoETA et al. (2012). Therefore, the comparison of other parameters than reverberation time should be conducted carefully and focused mostly between the measured rooms rather than the reference.

The next difference with respect to the standard is the number of measurement points, which is much lower than required. This is conditioned by time restrictions concerning access to the churches. In addition, the number of source positions was limited to two or three (depending on the size of the temple). The source was always located in front of the iconostasis and another control position (not far from the main point). This is a place where concerts, as well as the priest's sermons and chants, take place. The measurements were made in characteristic places, such as:

- behind the holy table (the first rows during concerts),

- in the middle of the temple (at least two positions),

- below the main dome,

- below the gallery,

- at the back of the temple,

- in the aisles (at least three positions),

- in other positions, if the shape was indicative of that.

In larger buildings, the number of measurements was greater, according to needs.
In order to register the spatial qualities of the acoustic field, the measurements were made with a Soundfield ST350 first-order ambisonic microphone. The ambisonic parameters were calculated on the basis of a B-format pressure component, with its frequency response being measured. As for the acoustical band, it consists of linear acoustics and the variation is not greater than $\pm 2 \mathrm{~dB}$. The acoustic properties of the measuring setup were captured in the AGH anechoic chamber. Its influence on the resulting impulse response of buildings was decreased by deconvolution. The directional character of sound sources is a known issue, but standard omni-directional sources have a poor and non-flat frequency response. Measurements of the listed rooms were conducted in summer 2012. The temperature was stable and varied from around $20^{\circ} \mathrm{C}$ to $30^{\circ} \mathrm{C}$.

\section{Results}

Out of the 20 measured rooms, the 8 most specific and representative ones were chosen on the basis of the analysis of acoustic parameters, geometry, architectural style and other qualities, using principal component analysis. Short descriptions of the church characteristics and the results of the research are introduced in the following subsections. Sketches and the basic measurements of each of the churches are presented. These include Reverberation time (T20) in octave bands, and the basic acoustic parameters, such as: Early Decay Time (EDT), clarity for music (C80), clarity for speech (C50), bass ratio (BR), treble ratio (TR), lateral energy fractions (JLF), speech transmission index (STI) and sound strength $(\mathrm{G})$. The parameters are discussed in detail in the handbooks for acoustics (BARRon, 2010; Rossing, 2007). The parameters, measured and calculated, are presented in the shape of statistical estimators: mean value and median value. In addition, the extreme values are given. All the frequency characteristics of reverberation time were plotted using the median value and extreme values. Nonparametric statistical estimators were used because of the large diversity in size and the acoustical field was observed. The following churches are introduced in ascending order in terms of their cubature.

\subsection{St Basil the Great Orthodox Church in Konieczna (KO)}

The church (Fig. 1) was built in 1903-1905 and consecrated in 1906. After the deportations of the locals (1947), the church served as a Catholic temple at times. Since 1969, it has functioned as an Orthodox church for the people who returned there. The church is numbered among the West Lemko Churches in terms of style (BRYKOWsKI, 1986). It is a wooden (fir tree) temple of a log frame structure, oriented on a square plan and composed of three sections. From the west, a threetier tower with straight walls adjoins to it. It is topped 

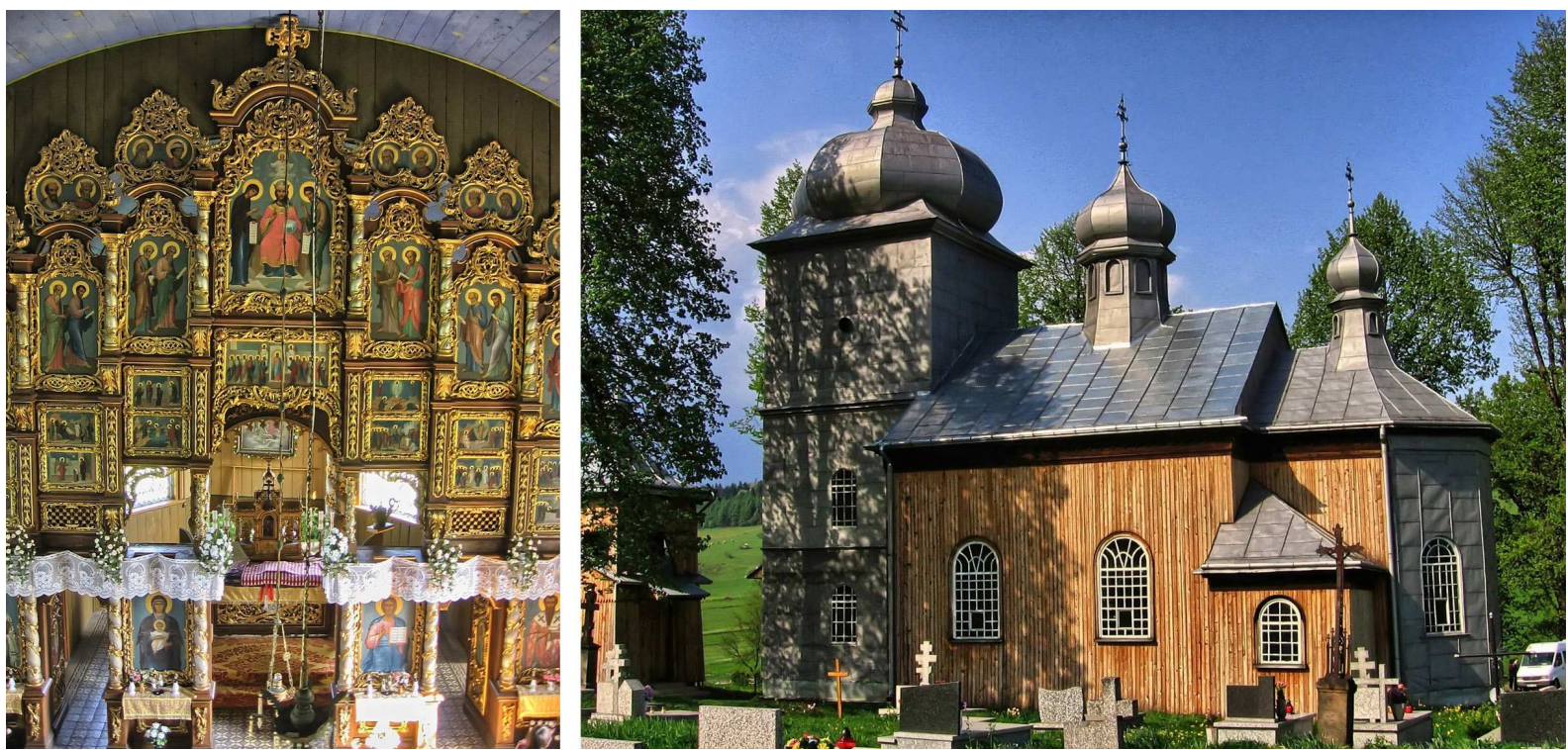

Fig. 1. St Basil the Great Orthodox Church in Konieczna (KO).

by a big onion dome without a lantern. There are two large, semicircular windows in the lateral walls of the chancel. An underslung gallery is located on the west wall of the aisle, additionally mounted on two wooden pillars, and there is an open gallery leading to the room in the tower. The porch (prytwor) is situated below the tower and fronts the aisle. Between the aisle and the presbytery, there is an architectural, wooden iconos- tasis brought from Ukraine in 1912. There is a small clearance above the Royal Doors.

The acoustic parameters of the St Basil Orthodox Church in Konieczna are shown in Tables 1-3. The reverberation time in the temple is short (Fig. 2), similar to the reverberation time in wooden Catholic churches built in this period in Poland (ENGEL et al., 2007). The frequency characteristics have a maximum at $1000 \mathrm{~Hz}$,

Table 1. Acoustic parameters (T20, EDT, STI) of the selected Orthodox churches in Poland.

\begin{tabular}{|c|c|c|c|c|c|c|c|c|c|}
\hline & \multicolumn{3}{|c|}{ T20 $[\mathrm{s}]$} & \multicolumn{3}{c|}{ EDT [s] } & \multicolumn{3}{c|}{ STI } \\
\cline { 2 - 11 } & Mean & Median & Extremes & Mean & Median & Extremes & Mean & Median & Extremes \\
\hline KO & 1.83 & 1.83 & $1.80-1.85$ & 1.81 & 1.8 & $1.76-1.89$ & 0.57 & 0.58 & $0.55-0.60$ \\
\hline SA & 1.17 & 1.16 & $1.15-1.23$ & 1.13 & 1.07 & $1.07-1.31$ & 0.67 & 0.67 & $0.60-.075$ \\
\hline HR & 1.82 & 1.82 & $1.77-1.85$ & 1.77 & 1.78 & $1.40-1.94$ & 0.62 & 0.61 & $0.54-0.75$ \\
\hline WL & 2.09 & 2.07 & $2.00-2.30$ & 1.92 & 1.87 & $1.78-2.05$ & 0.56 & 0.58 & $0.45-0.62$ \\
\hline TO & 2.87 & 2.86 & $2.82-2.94$ & 2.8 & 2.69 & $2.60-3.00$ & 0.51 & 0.5 & $0.42-0.58$ \\
\hline HS & 6.14 & 6.15 & $5.98-6.23$ & 5.87 & 5.8 & $5.71-6.06$ & 0.45 & 0.43 & $0.40-0.55$ \\
\hline HA & 4.59 & 4.61 & $4.51-4.64$ & 4.36 & 4.36 & $4.01-4.55$ & 0.45 & 0.43 & $0.37-0.56$ \\
\hline BI & 6.53 & 6.51 & $6.34-6.70$ & 6.65 & 6.48 & $6.48-6.74$ & 0.48 & 0.43 & $0.39-0.67$ \\
\hline
\end{tabular}

Table 2. Acoustic parameters (C80, BR, TR) of the selected Orthodox churches in Poland.

\begin{tabular}{|c|c|c|c|c|c|c|c|c|c|}
\hline & \multicolumn{3}{|c|}{ C80 $[\mathrm{dB}]$} & \multicolumn{3}{c|}{ BR } & \multicolumn{3}{c|}{ TR } \\
\cline { 2 - 11 } & Mean & Median & Extremes & Mean & Median & Extremes & Mean & Median & Extremes \\
\hline KO & 3.5 & 3.9 & $2.4-4.2$ & 0.88 & 0.9 & $0.84-0.92$ & 0.76 & 0.77 & $0.75-0.78$ \\
\hline SA & 7.3 & 7.7 & $3.7-10.6$ & 0.88 & 0.9 & $0.87-0.93$ & 0.88 & 0.9 & $0.87-0.93$ \\
\hline HR & 5.3 & 4.6 & $2.00-10.20$ & 1.1 & 1.05 & $1.0-1.1$ & 0.7 & 0.64 & $0.6-0.7$ \\
\hline WL & 2.1 & 2.6 & $-1.9-3.8$ & 1.21 & 1.25 & $1.07-1.29$ & 0.68 & 0.65 & $0.64-0.84$ \\
\hline TO & 0.5 & 0.3 & $-2.8-3.4$ & 1.34 & 1.32 & $1.31-1.39$ & 0.6 & 0.62 & $0.58-0.63$ \\
\hline HS & 0.3 & -0.6 & $-1.4-3.1$ & 0.96 & 0.97 & $0.93-0.99$ & 0.61 & 0.62 & $0.60-0.64$ \\
\hline HA & -0.4 & -1.1 & $-3.0-3.9$ & 1.04 & 1.06 & $0.93-1.08$ & 0.66 & 0.66 & $0.64-0.68$ \\
\hline BI & 1 & -0.4 & $-2.6-7.1$ & 0.98 & 0.98 & $0.92-1.02$ & 0.63 & 0.64 & $0.62-0.74$ \\
\hline
\end{tabular}


Table 3. Acoustic parameters (JLF, G, C50) of the selected Orthodox churches in Poland.

\begin{tabular}{|c|c|c|c|c|c|c|c|c|c|}
\hline & \multicolumn{3}{|c|}{ JLF } & \multicolumn{3}{c|}{ G [dB] } & \multicolumn{3}{c|}{ C50 [dB] } \\
\cline { 2 - 11 } & Mean & Median & Extremes & Mean & Median & Extremes & Mean & Median & Extremes \\
\hline KO & 3.5 & 3.9 & $2.4-4.2$ & 0.88 & 0.9 & $0.84-0.92$ & 0.76 & 0.77 & $0.75-0.78$ \\
\hline SA & 7.3 & 7.7 & $3.7-10.6$ & 0.88 & 0.9 & $0.87-0.93$ & 0.88 & 0.9 & $0.87-0.93$ \\
\hline HR & 5.3 & 4.6 & $2.00-10.20$ & 1.1 & 1.05 & $1.0-1.1$ & 0.7 & 0.64 & $0.6-0.7$ \\
\hline WL & 2.1 & 2.6 & $-1.9-3.8$ & 1.21 & 1.25 & $1.07-1.29$ & 0.68 & 0.65 & $0.64-0.84$ \\
\hline TO & 0.5 & 0.3 & $-2.8-3.4$ & 1.34 & 1.32 & $1.31-1.39$ & 0.6 & 0.62 & $0.58-0.63$ \\
\hline HS & 0.3 & -0.6 & $-1.4-3.1$ & 0.96 & 0.97 & $0.93-0.99$ & 0.61 & 0.62 & $0.60-0.64$ \\
\hline HA & -0.4 & -1.1 & $-3.0-3.9$ & 1.04 & 1.06 & $0.93-1.08$ & 0.66 & 0.66 & $0.64-0.68$ \\
\hline BI & 1 & -0.4 & $-2.6-7.1$ & 0.98 & 0.98 & $0.92-1.02$ & 0.63 & 0.64 & $0.62-0.74$ \\
\hline
\end{tabular}
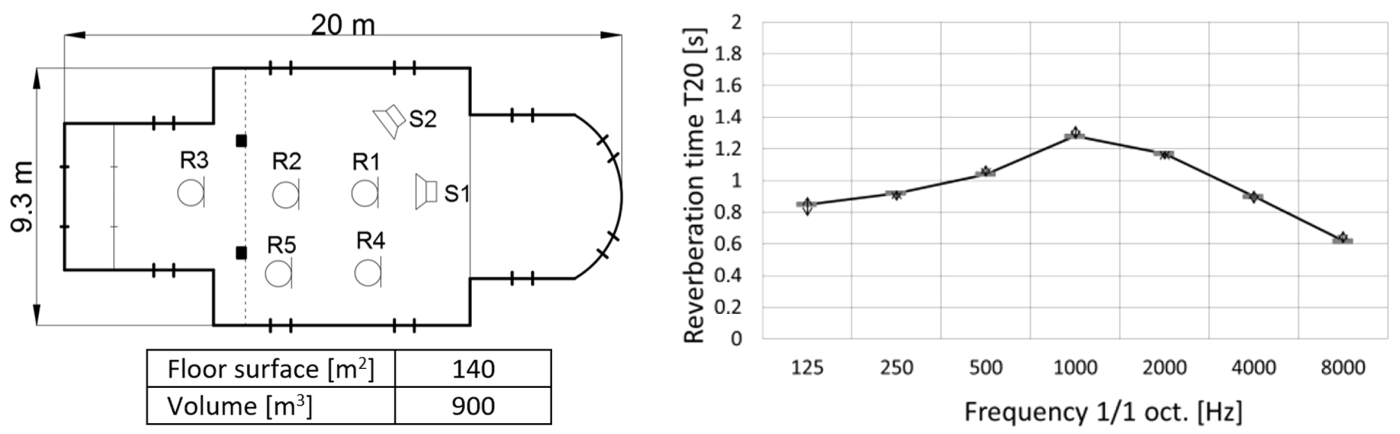

Fig. 2. Plan and the frequency characteristics of the reverberation time in the St. Basil the Great Orthodox Church in Konieczna (KO).

which is not common for religious buildings, typically reverberant, and influences, among others, the bass ratio BR which is relatively low. The parameters of the energy ratio (C80, C50) are high, which enables high transparency and speech understanding to be achieved, as well as the sharpness of music.

\subsection{Holy Trinity Orthodox Cathedral in Sanok (SA)}

The Conciliar Church (the counterpart of a cathedral church) of the Holy Trinity in Sanok (Fig. 3) was built in 1784-1789 on the site of the previous, wooden one, and used to function as a Greek Catholic parochial

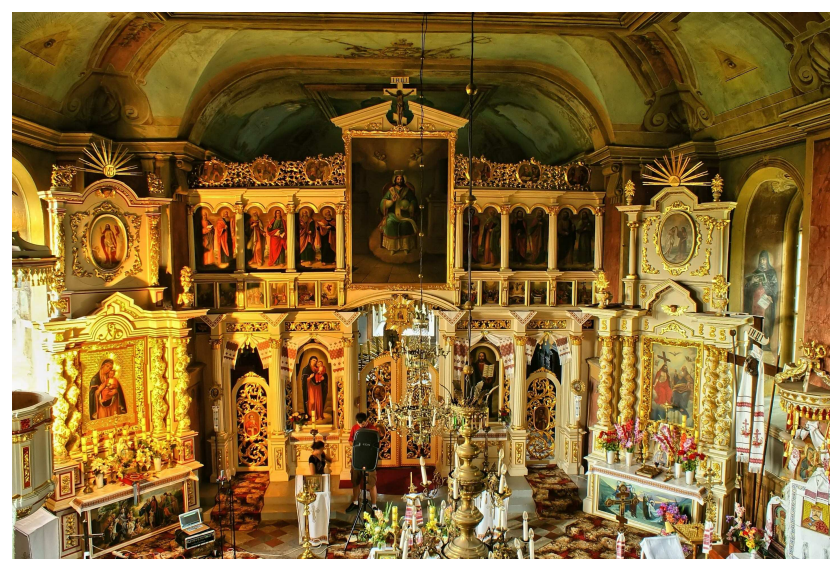

Fig. 3. Holy Trinity Orthodox Cathedral in Sanok (SA). town church. After the reconstruction in 1809, the church assumed the form of a building in the so-called, 'Joseph style'. The name derived from Joseph II, Emperor in the 18 th century. It is a variation of a late Baroque style with some elements of classicism. In the last decades of the 18th and the first decades of the 19th centuries, the style became the most popular of all in architecture, both for Orthodox and Catholic churches, in the countries which were under the influence of the Habsburg Monarchy (KRASNY, 2003). The church in Sanok is an oriented, brick-built (natural stone and brick) temple. Both the solid form of the temple and the spatial planning diverge from the standards of the Eastern Orthodox church scene. The church is composed of two sections, on a square plan and with a dominant broad aisle, as shown in Fig. 4.

The frequency characteristics for the reverberation time are the highest for the medium frequency (500$1000 \mathrm{~Hz}$ ). As for the low frequency, there is a wide variation of the values, which is probably caused by low frequency acoustic resonance. The temple is regular in terms of its shape and dimensions. The reverberation time, as well as most of the acoustic parameters shown in Tables 1-3, are similar to medium-sized Catholic churches in Poland (ENGEL et al., 2007; KosAlA, ENGEL, 2013; WroblewskA, KulOWSKI, 2007), which shows the influence of the Latin architectural styles. Apart from the reverberation time at low frequency, the values of individual parameters do not vary much 

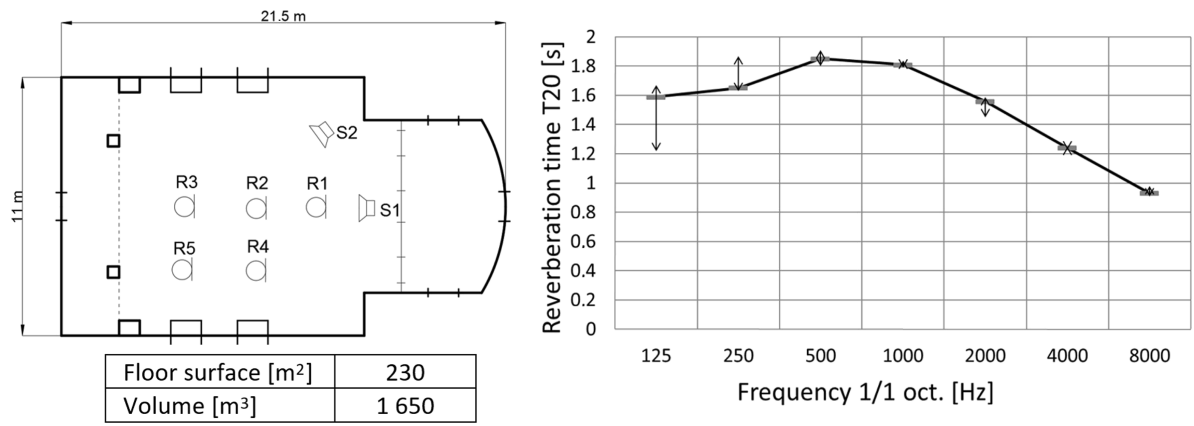

Fig. 4. Plan and the frequency characteristics of the reverberation time in the Holy Trinity Orthodox Cathedral in Sanok (SA).

with the places of the measurements, which shows that the acoustic field is highly diffused. The average values and the medians are similar.

\subsection{Dormition of the Virgin Mary Orthodox Church in Hrubieszów}

The church was built in $1873-1875$ on the site of the previous one, which was demolished in 1785 . The church is considered to be the most monumental among all of the temples in Poland. As for its structure, the building does not differ much from the other Or- thodox churches of that time, which were numbered among the Russo-Byzantine style buildings. However, its structure is more elaborate (CYNALEWSKAKuCzMA, 2004). The temple, which has twelve domes, was built according to the cross-domed plan in such a way that the three-part structure is clearly visible, as shown in Fig. 6. The sanctuary area is marked by a semi-circular shaped apse, to which a quadrangular aisle corpus adheres. Inside, an oak iconostasis stands, which reaches half of the clearance between the aisle and the altar. In addition, other elements characteristic of Orthodox churches are located inside (Fig. 5).
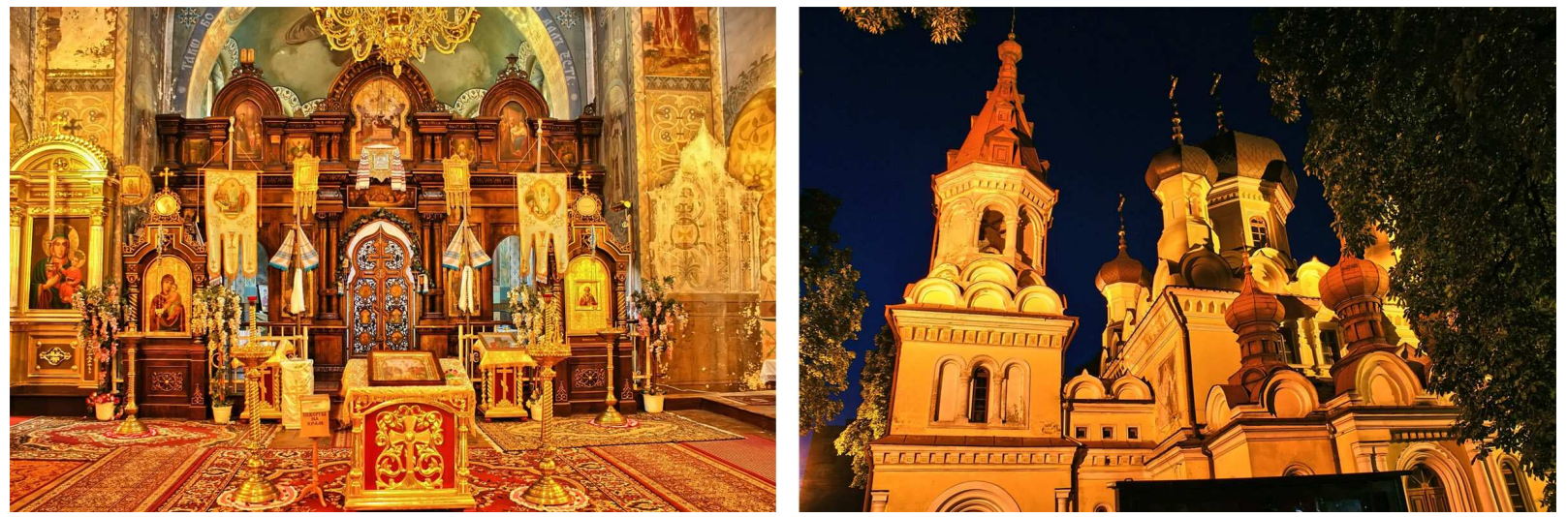

Fig. 5. Dormition of the Virgin Mary Orthodox Church in Hrubieszów (HR).
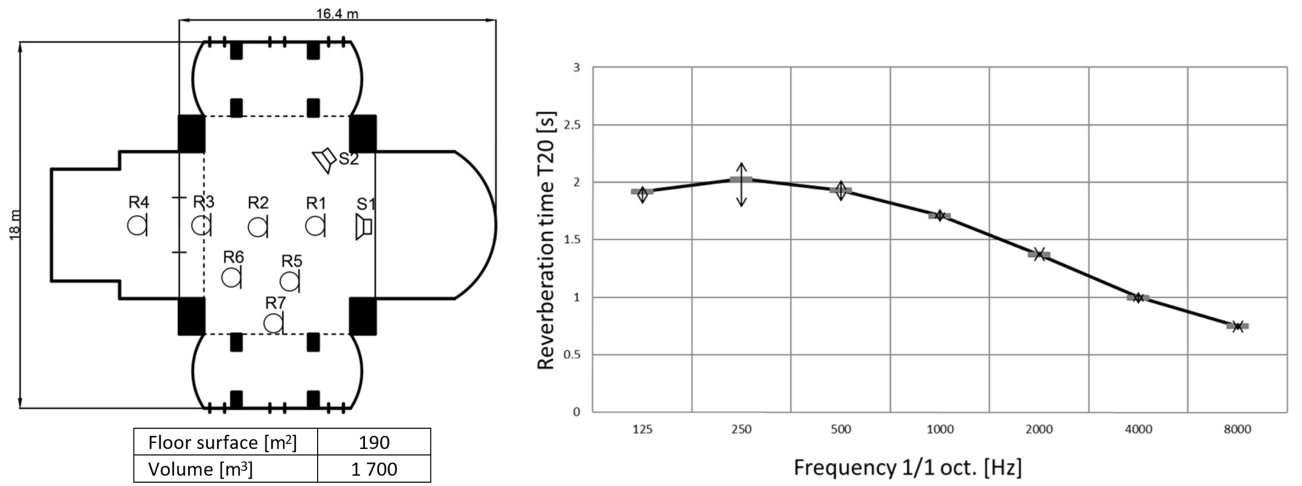

Fig. 6. Plan and the frequency characteristics of the reverberation time in the Dormition of the Virgin Mary Orthodox Church in Hrubieszów (HR). 
The frequency characteristics of the reverberation time shown in Fig. 6 are the highest for the low frequency. The parameters of the energy ratio $(\mathrm{C} 80, \mathrm{C} 50)$ vary quite considerably. In addition, the reverberation time for the $250 \mathrm{~Hz}$ frequency has more variable extrema than in the case of the other frequency band. The sound strength parameter $\mathrm{G}$ is not very high when compared to the other churches studied.

\subsection{Nativity of the Blessed Virgin Mary Orthodox Church in Wtodawa}

The church was built in $1840-1843$ as a Greek Catholic, parochial town church. The author of the project was from Saint Petersburg, but his name remains unknown. The temple assumed its current form after its reconstruction in 1893. It is a perfect example of a Russo-Byzantine style church (other names of the style that appear in the literature are: Byzantine, Russian, synodal, official, neo-Byzantine), (CYNALEWSKAKuczma, 2004; Seniuk, 1996). The building is oriented, of a cross-domed plan. The aisle is square, topped by an onion dome, with a cylindrical tholobate (drum). The arms of the temple's cross frame two annexes (from the South and the North), which are apsidally closed from the East and closed straight from the West. They are also topped by an arched, gambrel roof. Inside (Fig. 7), there is a complete iconostasis dating from the time when the temple was built; other elements characteristic for Orthodox churches are also placed there (kiots, icons, processional banners etc.).

The acoustic parameters have very different values, depending on the place measured, as shown in Tables 1-3. There are several points where the frequency characteristics of the reverberation time for $500 \mathrm{~Hz}$ and $1000 \mathrm{~Hz}$ have much higher values than in others (Fig. 8). Probably, this is somehow related to the main dome's geometry and its acoustic influence

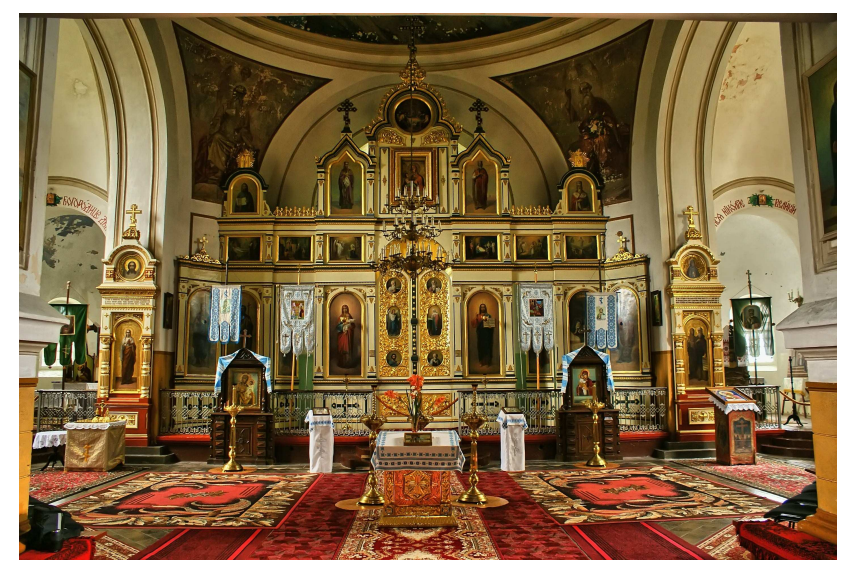

Fig. 7. Nativity of the Blessed Virgin Mary Orthodox Church in Włodawa (WL).

over the rest (which is the result of the accumulation of repercussions in some areas). The bass ratio BR, as well as sound strength $\mathrm{G}$, are high; the reverberation time is rather short for this room volume.

\subsection{St. Nicholas the Wonderworker Orthodox Church in Tomaszów Lubelski}

The author of the project was Konstanty Drozdowicz, who also supervised the works. The church was consecrated in 1890. Its style is described as neoRussian; it is one of the latest churches of this style; later, the neo-Byzantine style took over (DMiTRuk, 2008; Krasny, 2003). The structure is cross-domed. In the middle, above the point where the arms cross, an octagonal, onion dome soars. Above the annexes, which fill in the space between the arms of the cross, there are four kokoshniks similar in terms of the structure. The iconostasis inside reaches half the height of the presbytery. After the deportations in 1946, the church served as a repository; that is why none of
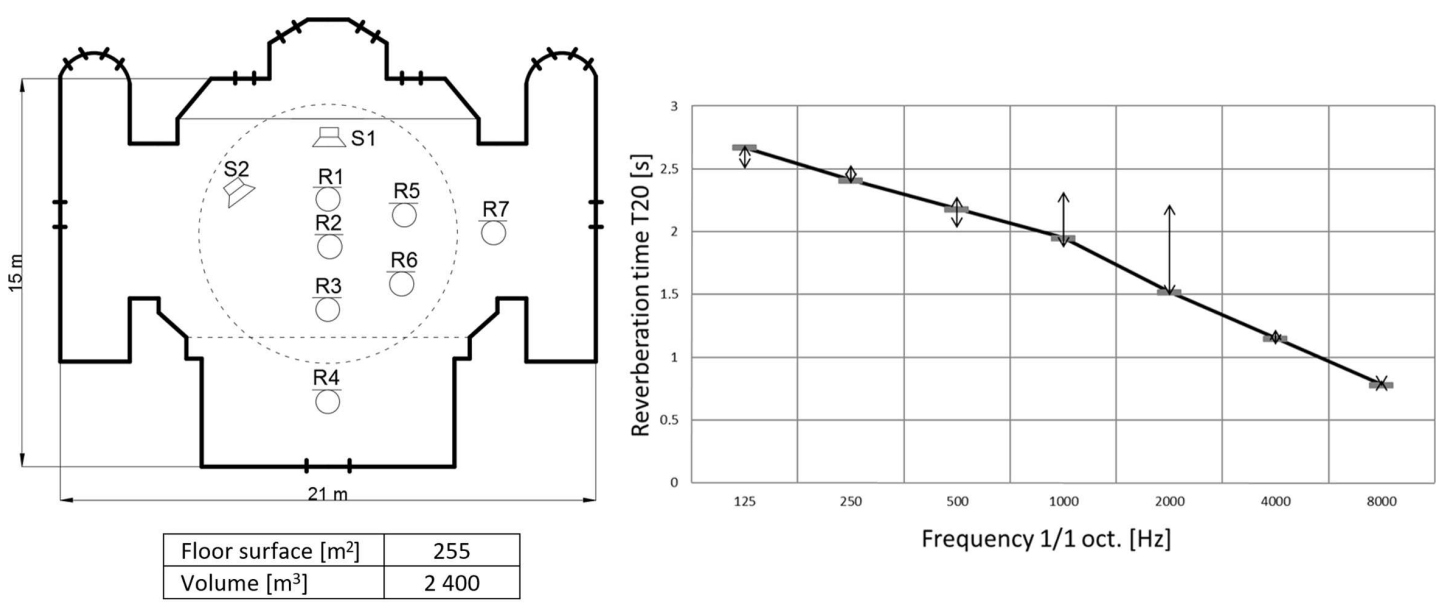

Fig. 8. Plan and the frequency characteristics of the reverberation time in the Nativity of the Blessed Virgin Mary Orthodox Church in Włodawa (WL). 
the original equipment, apart from the iconostasis, survived. The current state of the interior is shown in Fig. 9.

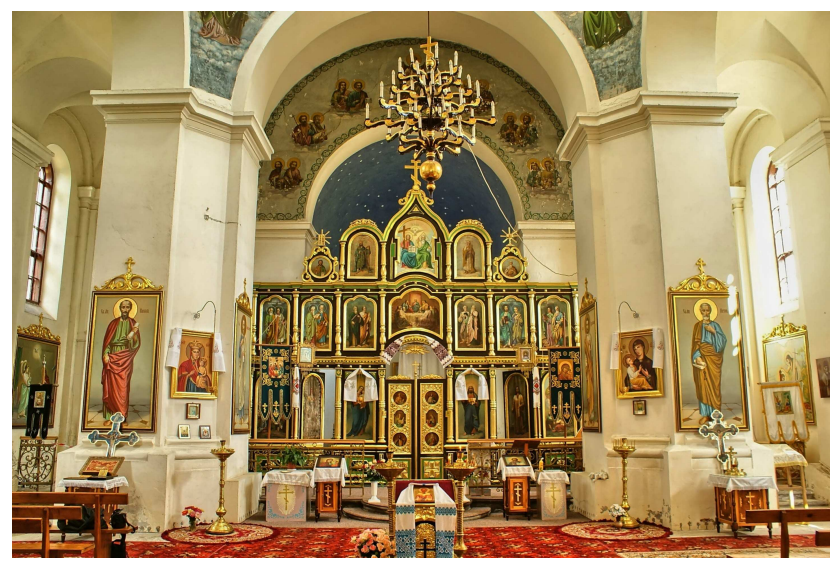

Fig. 9. St. Nicholas the Wonderworker Orthodox Church in Tomaszów Lubelski (TL).

The acoustic parameters are characterized by a large variation of extreme values (Tables $1-3$ ). The frequency characteristics of the reverberation time have the highest values for low frequencies (Fig. 10). This means that the bass ratio BR is relatively high.
The extreme values do not vary much for the whole acoustic frequency range and the decline of the reverberation time value, as well as the frequency, are regular.

\subsection{The Orthodox Church of the Holy Wisdom (Hagia Sophia) in Białystok}

The church was consecrated in 1998. The author of the temple's project was Michał Bałasz who specialized in religious architecture (both of Orthodox and Catholic churches). In terms of architecture, the church resembles the most important temple for East Orthodox Christianity, that is, Hagia Sophia in Istanbul. The architect wanted the church in Białystok to be the counterpart of the one in Turkey (1:3), (PAKP, 2008). It is a brick-built, oriented temple, consisting of three aisles. The structure is a connection of a basilica system and a central plan. The main part of the aisle consists of a square (side length of $13 \mathrm{~m}$ ), and its borderlines are marked by a lateral and a west arcade. The dome's base has a diameter of about $12 \mathrm{~m}$, the dome is located at a height of $13.6 \mathrm{~m}$. The dome's coping reaches $22.1 \mathrm{~m}$ (the dome alone reaches $8.5 \mathrm{~m}$ ). The iconostasis septum is low and is made of marble (Fig. 11). The plan and the frequency characteristics of
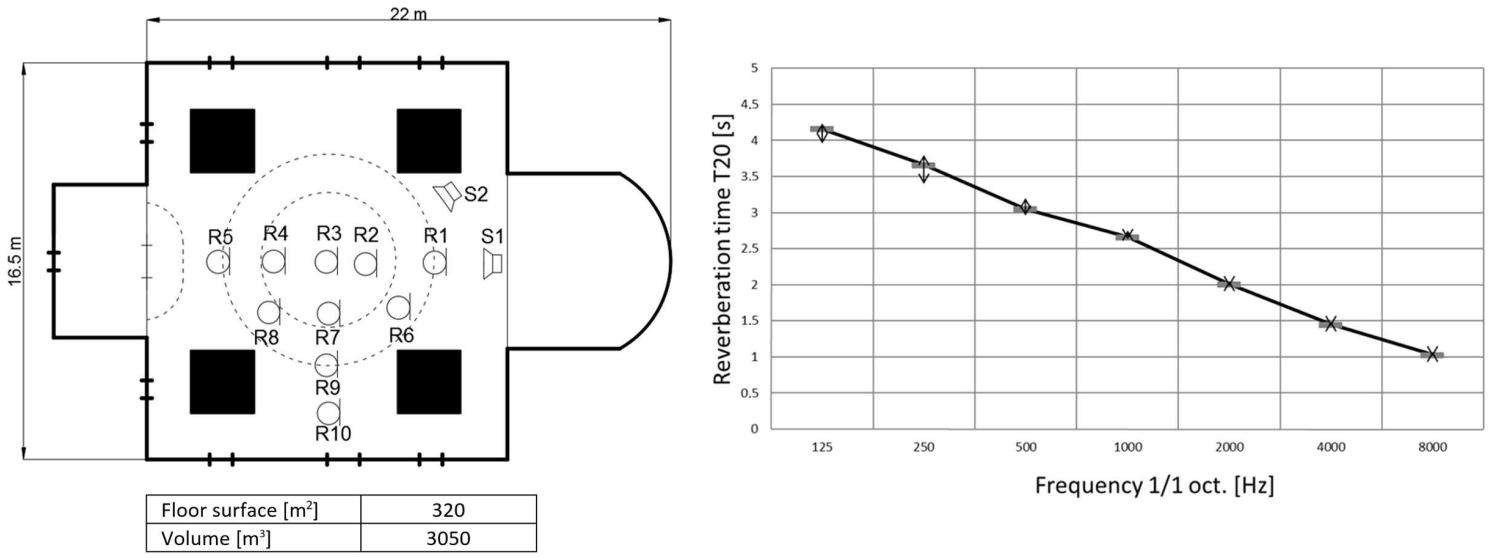

Fig. 10. Plan and the frequency characteristics of the reverberation time in the St. Nicholas the Wonderworker Orthodox Church in Tomaszów Lubelski (TL).
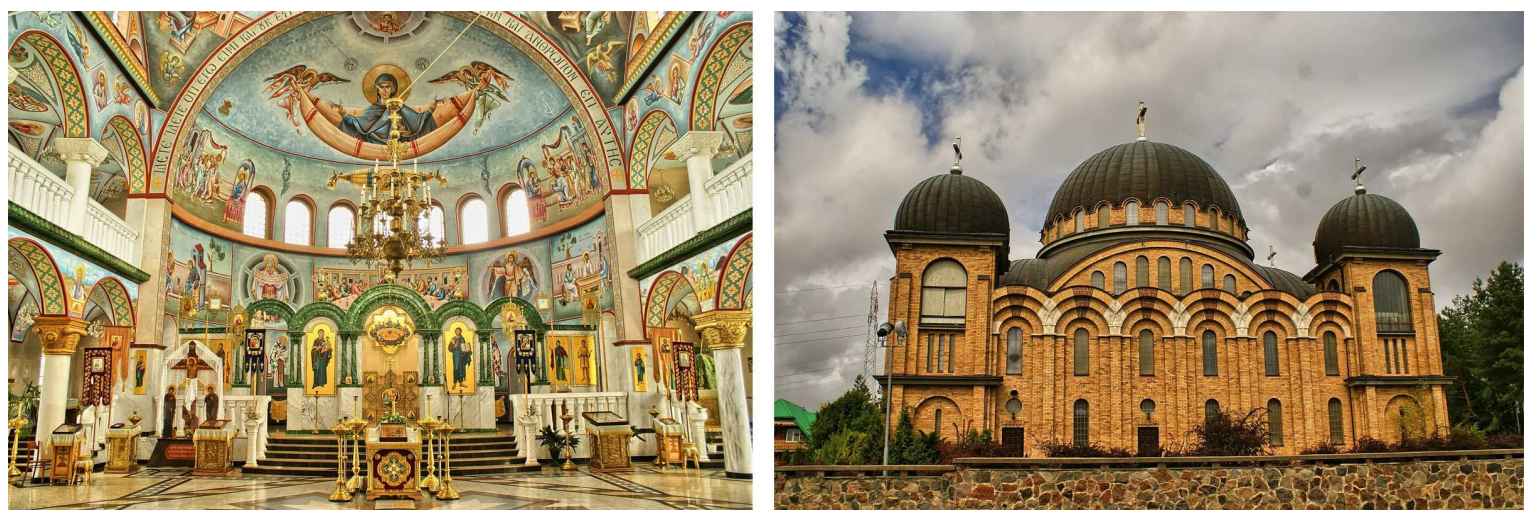

Fig. 11. The Orthodox Church of the Holy Wisdom (Hagia Sophia) in Białystok (HS). 

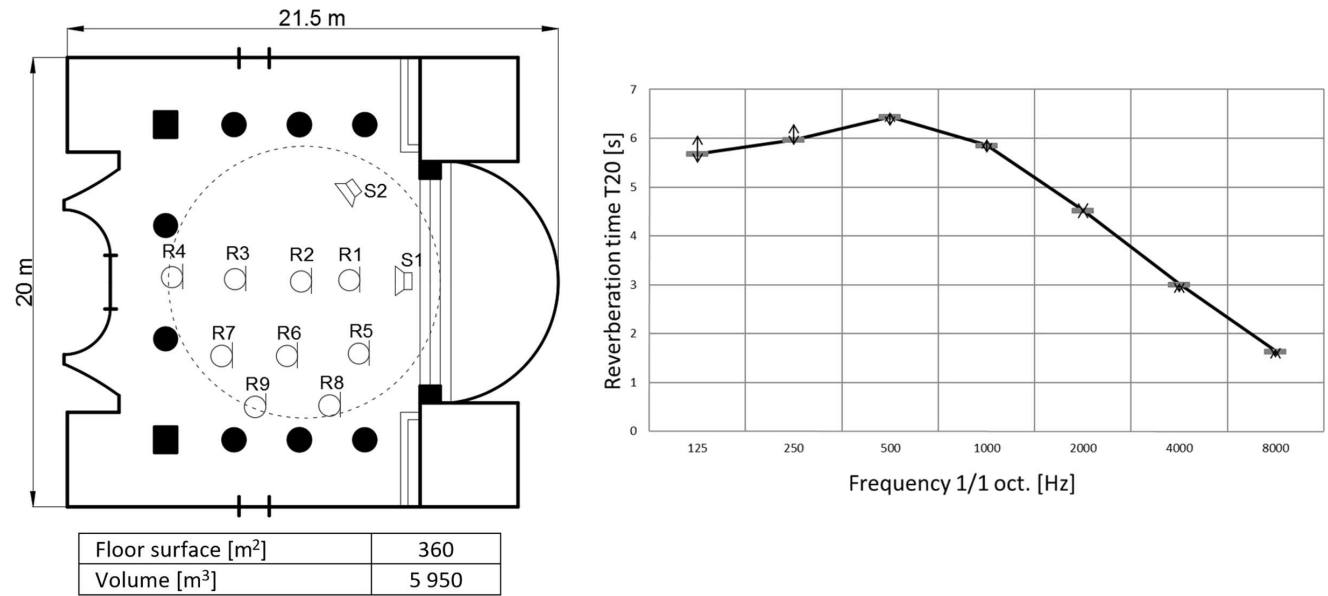

Fig. 12. Plan and the frequency characteristics of the reverberation time in the Orthodox Church of the Holy Wisdom (Hagia Sophia) in Białystok (HS).

the reverberation time in the Orthodox Church of the Holy Wisdom (Hagia Sophia) in Białystok are shown in Fig. 12.

The reverberation time in the temple is quite long. The frequency characteristics of the reverberation time are maximum for the medium frequency. As a result, the bass ratio BR is low. This is very unusual for such large rooms. It is a very interesting church in terms of its similarity to the Hagia Sophia in Istanbul. If the possibility of a comparative analysis between these two arises, research into the acoustic changes caused by untypical geometry could be made. The acoustic parameters of the Orthodox Church of the Holy Wisdom (Hagia Sophia) in Białystok listed in Table 2 show quite a difference in comparison to the previous buildings. The lower values of STI and energy parameters are the result of long T20 and EDT (Table 1).

\subsection{Holy Trinity Orthodox Cathedral in Hajnówka}

This revolutionary project in the architecture of Polish Orthodox churches was created by Aleksander Grygorowicz. The interior (Fig. 13) was put into service in 1982, but the finishing works lasted for a few more years. The project is based on the cross-domed plan (Fig. 14). The central tower-dome (almost $50 \mathrm{~m}$ high) is based on four stanchions, each of them with a diameter of one meter; the two remaining stanchions located on the west side serve as a base for the gallery. The temple is a reference to the Old Russian churches. Some architecture experts also see a French architect's influence in the project - Le Corbusier. A tapered dome is topped by a quadrangular lantern by Jerzy Nowosielski. The length of the building is $35 \mathrm{~m}$ and the width $-30 \mathrm{~m}$. The iconostasis is low and consists
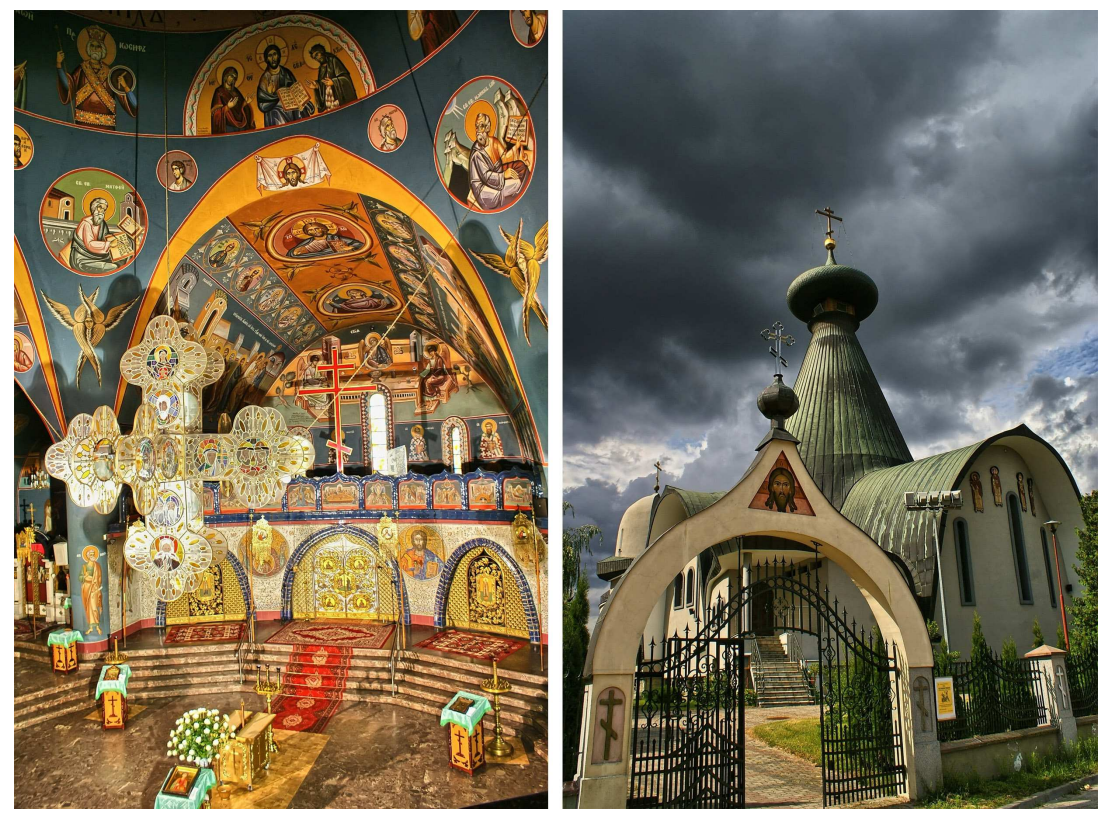

Fig. 13. Holy Trinity Orthodox Cathedral in Hajnówka (HA). 

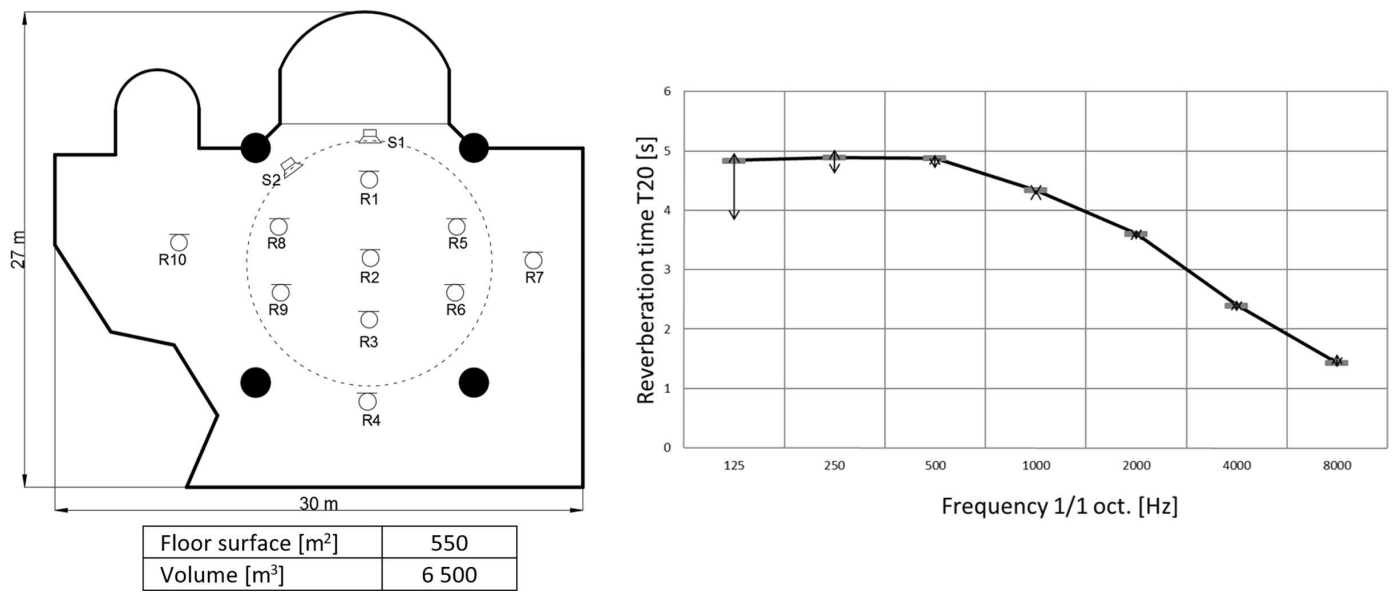

Fig. 14. Plan and the frequency characteristics of the reverberation time in the Holy Trinity Orthodox Cathedral in Hajnówka (HA).

of two rows; the balustrades are made of concrete, a mosaic brought from Kharkiv was put on it, as well as other ceramic elements (doorposts) and metalwork parts (Royal and Deacon Gates). The church in Hajnówka is famous for the International Festival of Orthodox Church Music event. There, Orthodox Church music performances by choir ensembles from all over the world take place. The choirs are led by prominent conductors with vast experience and music knowledge. The temple has already been studied in terms of its acoustics in the author's pilot research concerning the acoustics of Orthodox churches (MAŁECKI, WICIAK, 2011). It has been evaluated highly in comparison to the other churches.

The reverberation time is relatively long, although it is shorter with respect to the other churches similar in size (Table 1). The variation of the parameters within the building is significant despite the irregular construction, which should normally cause diffusion of the sound field. The frequency characteristics of the reverberation time are flat for the low frequency; however, they decrease for the medium and high frequencies. The diversity of the reverberation time length is relevant only for the low frequency; here, it differs significantly from the median and the maximum value.
The widely known acoustic advantages of the church in Hajnówka are also testified to by the annual festival. The event constitutes a relevant baseline for the analysis and interpretation of further research.

\subsection{Orthodox Church of the Holy Spirit in Biatystok}

The monumental temple's project was made by the architect Jan Kabac. It was consecrated on May 16, 1999. It is the biggest church in Poland as regards the cubature. Because of the five-dome structure, the church is similar to the one in Novgorod. It is a two-story church; in the upper part, a central plan was applied. The aisle, which was planned according to the octagonal scheme (the length of one side is $10 \mathrm{~m}$ ), is topped by a divided dome (the dome turns into a lantern topped by a shallow dome at $2 / 3$ of its height $-7 \mathrm{~m})$. An oak, architectural iconostasis is located between the presbytery and the aisle. It is the highest iconostasis in Poland; the height of the Royal Gate is $10 \mathrm{~m}$ and the height of the doors alone is $8 \mathrm{~m}$. The iconostasis is connected to the iconostasis of the southern chapel (the whole length is $17.2 \mathrm{~m}$ ). The temple seats 2,500 people altogether and its interior is shown in Fig. 15. The surface of the polychromy
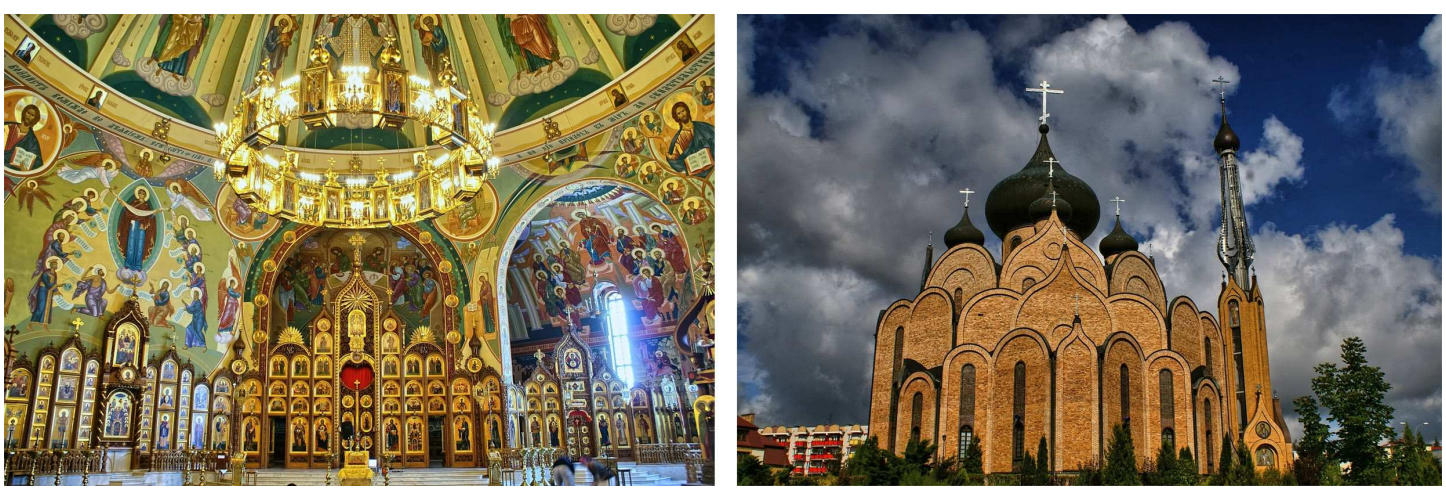

Fig. 15. Orthodox Church of the Holy Trinity Orthodox Cathedral in Hajnówka (HA). 

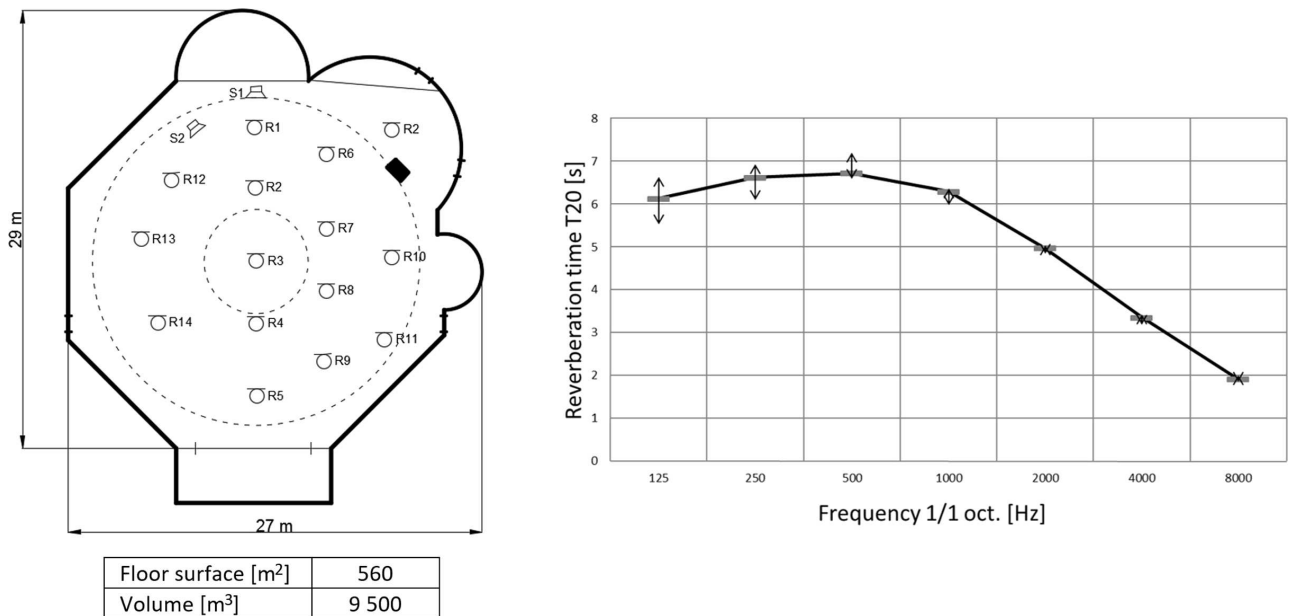

Fig. 16. Plan and the frequency characteristics of the reverberation time in the Orthodox Church of the Holy Spirit in Białystok (BI).

is about $5,000 \mathrm{~m}^{2}$. The plan and the frequency characteristics of the reverberation time in the Orthodox Church of the Holy Spirit in Białystok are shown in Fig. 16.

The considerable size of the temple, as well as the fact that there are few sound absorbing materials, make the reverberation time long. The highest values of T20 appear for mid-frequency. In spite of the high diffusivity of the acoustic field, there is a significant variation of extreme values and a big difference between the medium value and the median. The average value of the sound strength $G$ is low and, surprisingly enough, it is similar to the values of small rooms (Table 3$)$.

\section{Discussion and conclusion}

The architectural and acoustic characteristics of particular churches in Poland have been introduced. The presentation covers typical and prevalent types of temples of Eastern Christianity. The overview presents a wide range of temples in terms of the structure: there are examples of monumental ones, as well as small, local churches; historical ones and some which are unique for various reasons. The cubature of the churches lies between $900-9500 \mathrm{~m}^{3}$ and the reverberation time: 1.1-6.5 s. The comparison to Greek, Russian and Serbian Orthodox (Elicio, Martellotta, 2015) churches presented in Fig. 17 shows that up to a volume of $3000 \mathrm{~m}^{3}$ (room id: TO), T20500 Hz of measured rooms is lower than the regression curve calculated on the basis of all available Orthodox churches considered in this reference. Plotted values of T20500 Hz were derived from the regression curve using the same volumes of the analyzed churches. Larger churches have a higher $\mathrm{T} 20_{500 \mathrm{~Hz}}$ than the regression curve, and the difference is very high for HS and BI. This is probably a result of many small textile elements in small

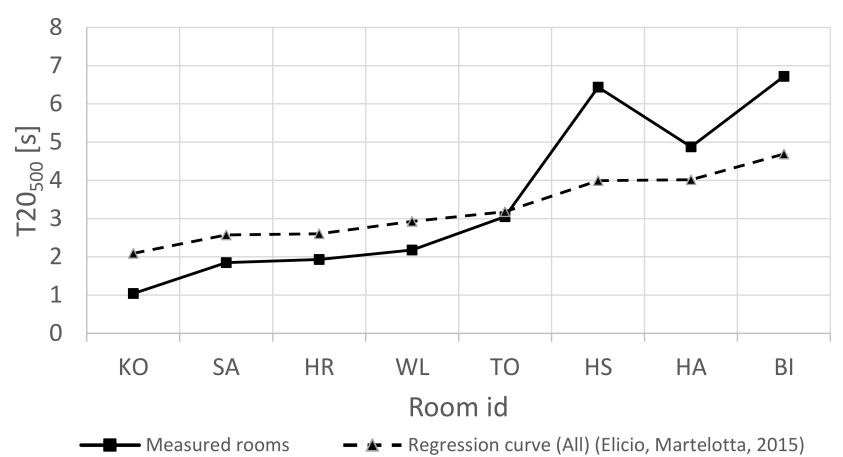

Fig. 17. Reverberation time at $500 \mathrm{~Hz}$ of selected Orthodox churches in Poland in comparison with the regression curve of Greek, Russian and Serbian Orthodox churches (ELICiO, Martellotta, 2015).

and medium churches, in contrast with large churches which are very austere in that aspect. The clarity for music parameter $(\mathrm{C} 80)$ shown in Fig. 18 decreases with the volume of rooms, except for the $\mathrm{KO}$ church, which is made of wood. In addition, it does not suit the trend for speech intelligibility. An interesting point is that

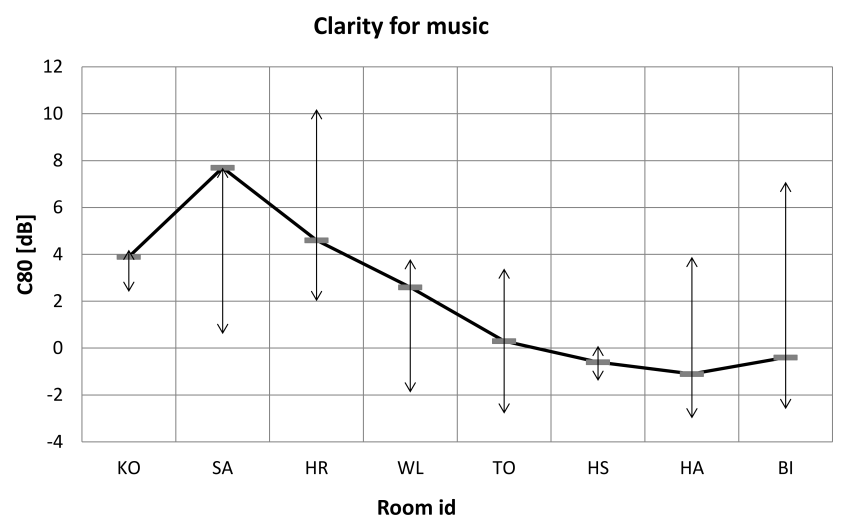

Fig. 18. Clarity for music (C80) in the selected Orthodox churches in Poland. 
the extreme value distribution is different for almost every case. HS, which is similar in many aspects to $\mathrm{HA}$, has almost the same values of C80 at every measuring point. According to Kulowski (2011), the C80 parameter close to the source should be higher than $3 \mathrm{~dB}$. Only for the HS church is it much lower. Far from the sound source, it is recommended for C80 to be higher than $0 \mathrm{~dB}$. Most of the median and average values shown in Table 2 are higher than that or very close to it. Generally, the high variation of the energy based parameters could be a result of the use of a directional sound source and dome-shaped ceiling. The sound strength parameter shown in Fig. 19 is quite high for all churches. As suggested by Beranek for concert halls, $5 \mathrm{~dB}$ is reached in the mean value for all churches. Only the HR church has quite low values in comparison to the other objects. Such high values (the maximum obtained values are very high for the SA, WL, TO and HS churches) are important in the aspect of singing music, which is regularly performed in Orthodox churches. In addition, on the basis of Fig. 20, the lateral energy fraction parameter is high for all churches except HR. For concert halls, the values of JLF (HYDE, 1994) should be from 0.15 to 0.25 . Of course, for houses of worship, by intuition, it is desirable to surround a listener and it is not so important to produce a focus sound source image This assumption

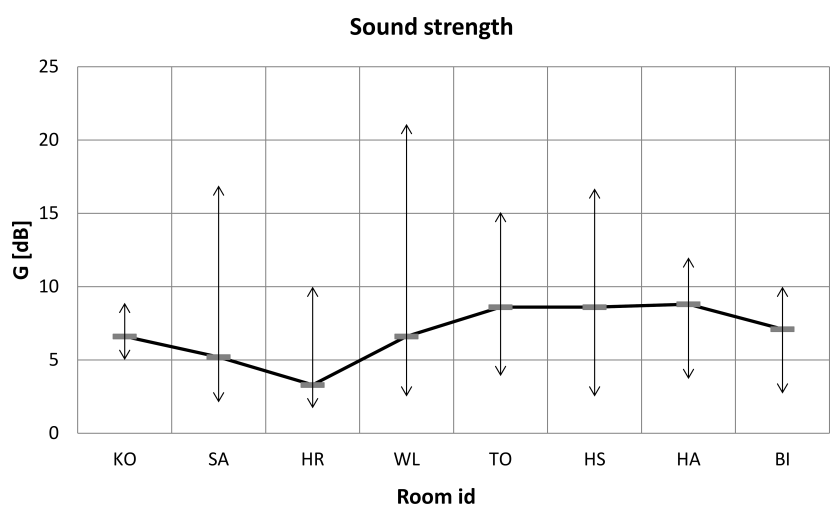

Fig. 19. Sound strength $(\mathrm{G})$ of the selected Orthodox churches in Poland.

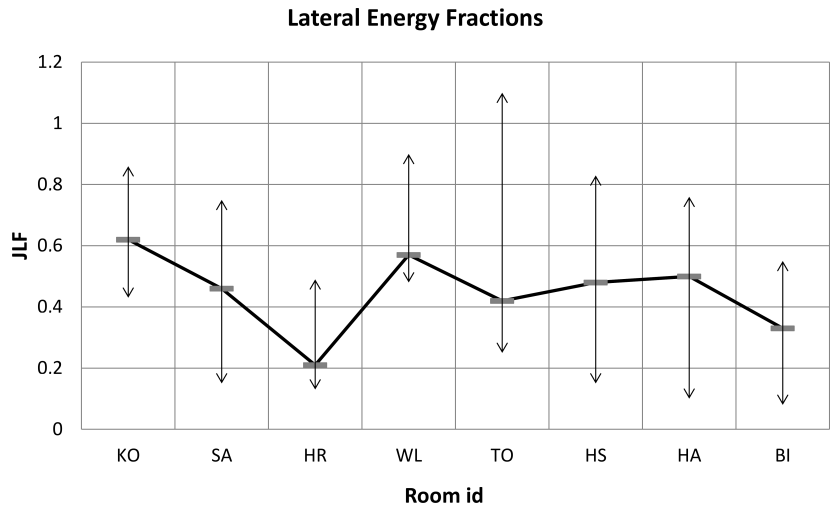

Fig. 20. Lateral Energy Fractions (JLF) of the selected Orthodox churches in Poland. corresponds also with results of (MARTELLOTTA, 2008) where test subjects preferred higher values of JLF for the Catholic churches. The speech intelligibility index (STI) is higher than 0.45 for all the churches that have lower $\mathrm{T}_{20} 0_{500}$ than the regression curve in Fig. 17. Furthermore, for highly reverberant churches (HS, HA and $\mathrm{BI}$ ), STI is not lower than 0.4 , so the intelligibility is not bad even in these buildings (Fig. 21). The mean and median values of STI (Table 1) are similar to the minimum obtained values, but there are some measuring points where speech intelligibility is good.

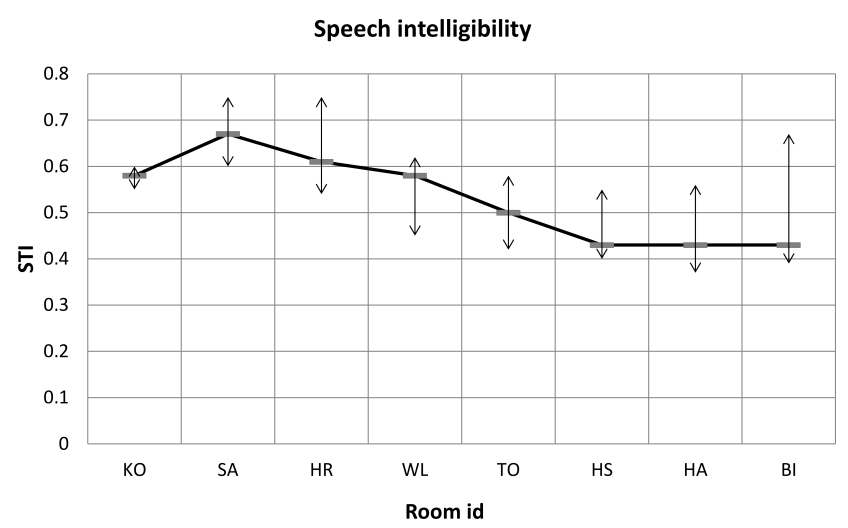

Fig. 21. Speech intelligibility (STI) of the selected Orthodox churches in Poland.

The next stage of the research is an auditory evaluation of the sound quality of the studied rooms' acoustics. They are evaluated in terms of the usage, that is, choir music performance inside, which remains as (almost) the only source of music allowed there. The obtained results show a wide deviation of all the acoustic parameters, so it is difficult or almost impossible to make any general remarks. Due to the many small architecture elements in all of the measured churches, their sound field diffusion is higher than in modern Roman Catholic churches.

\section{References}

1. Álvarez-Morales L., Girón S., Galindo M., ZaMARREÑo T. (2016), Acoustic environment of Andalusian cathedrals, Building and Environment, 103, 182192.

2. Álvarez-Morales L., Martellotta F. (2015), A geometrical acoustic simulation of the effect of occupancy and source position in historical churches, Applied Acoustics, 91, 47-58.

3. Álvarez-Morales L., Zamarreño T., Girón S., Galindo M. (2014), A methodology for the study of the acoustic environment of Catholic cathedrals: Application to the Cathedral of Malaga, Building and Environment, 72, 102-115.

4. BARron M. (2010), Auditorium acoustics and architectural design, Spon Press, New York. 
5. BRYKowski R. (1986), Lemko style wooden Orthodox church architecture in Poland, Slovakia and Carpathian Ruthenia [in Polish], Ossolineum, Wrocław.

6. BRYKowski R. (1995), Wooden Orthodox church architecture [in Polish], Towarzystwo Opieki nad Zabytkami, Warszawa.

7. Carvalho A.P., Morgado A.E. (1997), Relationships between speech intelligibility and objective acoustical parameters for architectural features in Catholic churches, Journal of Acoustical Society of America, 101, 3051-3052.

8. Cynalewska-Kuczma P. (2004), Orthodox church architecture in the Polish Kingdom as an integrity tool with the Russian Empire [in Polish], Uniwersytet A. Mickiewicza, Poznań.

9. Dmitruk S. (2008), About Tomaszów parish [in Polish], Przegląd Prawosławny, 2.

10. Elicio L., Martellotta F. (2015), Acoustics as a cultural heritage: the case of Orthodox churches and of the "Russian church" in Bari, Journal of Cultural Heritage, 16, 912-917, doi: 10.1016/j.culher.2015.02.001.

11. Engel Z., KosaŁa K., Sadowski J. (2007), Fundamentals of sacred building acoustics [in Polish], PiB, Kraków-Radom.

12. Galindo M., Zamarreño T., Girón S. (2000), Speech intelligibility in Mudejar-Gothic churches, Acta Acustica united with Acustica, 86, 381-384.

13. Hyde R.J. (1994), Development of modern room acoustic parameters from Sabine's reverberation theory. The role of acoustical measurement in design criteria for auditoria, Proceedings of Wallace Clement Sabine Centennial Symposium, Massachusetts.

14. ISO 3382-1 (2009), Acoustics - Measurement of the Reverberation Time of Rooms with Reference to other Acoustical Parameters, ISO, Geneva.

15. Koєbuk W. (1998), Eastern churches in Poland around 1772 [in Polish], Instytut Europy ŚrodkowoWschodniej, Lublin.

16. Kosata K. (2016), Calculation models for acoustic analysis of St. Elizabeth of Hungary Church in Jaworzno Szczakowa, Archives of Acoustics, 41, 3, 485498, doi: 10.1515/aoa-2016-0047.

17. Kosala K., Engel Z.W. (2013), Assessing the acoustic properties of Roman Catholic churches: A new approach, Applied Acoustics 74, 1144-1152.

18. KRASNy P. (2003), Orthodox church architecture on Ruthenian lands [in Polish], Universitas, Kraków.

19. Kulowski A. (2011), Acoustics of halls. Design recommendation for architects. Wydawnictwo Politechniki Gdańskiej, Gdańsk.

20. Lubman D., Wetherill E. (1985), Acoustics of worship spaces, American Institute of Physics, New York.
21. MaŁecki P., Wiciak J. (2011), Acoustic parameters of chosen orthodox churches overview and preliminary psychoacoustic tests using choral music, Proceedings of 130th AES Convention, London, UK.

22. MaŁecki P., Zastawnik M., Wiciak J., Kamisiński T. (2011), The influence of the measurement chain on the impulse response of a reverberation room and its application listening tests, Acta Physica Polonica A, 119, 1027-1030.

23. Martellotta F. (2016), Understanding the acoustics of Papal Basilicas in Rome by means of a coupledvolumes approach, Journal of Sound and Vibration, 382, 413-427.

24. Martellotta F., Cirillo E., Carbonari A., RicCIARDI P. (2009), Guidelines for acoustical measurements in churches, Applied Acoustics, 70, 378-388.

25. Martellotta F. (2008), Subjective study of preferred listening conditions in Italian Catholic churches, Journal of Sound and Vibrations, 317, 378-399.

26. MiJic M. (2001), Serbian orthodox church - an acoustical view, Proceedings of 17th ICA, Rome.

27. Misic M., Sumarac-Pavlovic D. (2000), Acoustical characteristics of old wooden churches in Serbia, Journal of Acoustical Society of America, 108, 2648-2648.

28. PAKP (2008), Orthodox Calendar for 2008 [in Polish], Redakcja Warszawskiej Metropolii Prawosławnej, Warszawa.

29. Plewa M. (2007), Analysis of sound field in dominicans' church in Cracow, Archives of Acoustics, 32, 4(S), 227-233.

30. Rossing T. (2007), Handbook of Acoustics, Springer, Stanford.

31. SENiuK B. (1996), Orthodox churches of the Lublin province of Siedlce that have been executed by the project architect Syczugowa Victor Ivanovich, a member of the Imperial Academy of Fine Arts in St. Petersburg [in Polish], Proceedings of conference on sacral architecture development from $\mathrm{X}$ to $\mathrm{XX}$ century in Chełm diocese, Chełm.

32. Soeta Y., Ito K., Shimokura R., Sato S., OHSAWA T., ANDo Y. (2012), Effects of sound source location and direction on acoustic parameters in Japanese churches, The Journal of the Acoustical Society of America, 131, 2, 1206-1220, doi = 10.1121/1.3676697.

33. Valière J.C., Palazzo-Bertholon B., Polack J.D. (2013), Acoustic pots in Ancient and Medieval buildings: Literary analysis of ancient texts and comparison with recent observations in French churches, Acta Acustica united with Acustica, 99, 70-81.

34. Wroblewska D., Kulowski A. (2007), The acoustics factors in church designing, Wydawnictwo Politechniki Gdańskiej. 